\title{
Main Bank Relationship and Accounting Conservatism: Evidence from Japan
}

Hideaki Sakawa and Naoki Watanabel 


\title{
Main Bank Relationship and Accounting Conservatism:
}

\author{
Evidence from Japan* \\ Hideaki Sakawa ${ }^{+}$, \\ Nagoya City University/Columbia Business School \\ Naoki Watanabel \\ Nagoya City University
}

\begin{abstract}
In a market-oriented economy like the U.S., the process of monitoring through lending mitigates lenders' demand for accounting conservatism. Japanese corporate governance is characterized as a bank-dominated or relationship-oriented system. Under bank-dominated systems, main banks are expected to be effective monitors. In our model, main banks play the role of reducing the lenders' demand for accounting conservatism by reducing information asymmetry. We find that main banks can reduce the demand for accounting conservatism. Our findings help understand accounting conservatism vis-à-vis agency problems. We provide empirical evidence to contribute to literature on banking, specifically to fields such as relationship banking.
\end{abstract}

Keywords: Accounting conservatism; Agency Problem; Corporate Governance; Main Bank

\footnotetext{
* We thank Sudipta Basu, Jayson Talakai, Fumiko Takeda, and Yoshiro Tsutsui for their insightful comments. We would like to thank the participants of Asian Pacific Conference on International Accounting Issues, International Congress on Banking, Economics, Finance, and Business (BEFB), Association of Japanese Business Studies, Academy of International Business, and the American Accounting Association. This study is financially supported by the Grant-in-Aid for Young Scientists (A) (MEXT/JSPS KAKENHI Grant Number 17H04784), the Grant-in-Aid for Scientific Research (C) (MEXT/JSPS KAKENHI Grant Number 17K03695), and the Grant-in-Aid for Scientific Research (B) (MEXT/JSPS KAKENHI Grant Number 17KT0036).

+ Corresponding author. E-mail addresses: sakawa@econ.nagoya-cu.ac.jp_(H. Sakawa), naoki-watanabe@econ.nagoya-cu.ac.jp (N. Watanabel)
} 


\section{Introduction}

Conservatism accounting presents an asymmetric timeline of earnings from a higher degree of verification to recognize good news as accounting gain than bad news as loss (Basu, 1997). From the perspective of the agency theory, shareholders have an incentive to appropriate wealth from debt holders (Jensen and Meckling, 1976). There are two key drivers of conservatism: agency costs and information asymmetry (Basu, 1997; Watts, 2003a). A major source of demand for accounting conservatism arises from debt contracts (Watts, 2003a). However, accounting conservatism cannot fully solve the agency problems related to debt contracts (Erkens et al., 2014). Asymmetric information matters in the occurrence of severe agency problems. Previous literature on corporate governance conceptualizes that monitoring roles of corporate governance systems are differently characterized under different institutional settings (Aguilera et al., 2015). Thus, large U.S. firms are not necessarily effective in different corporate governance settings as bank-dominated corporate governance endeavors in Japan are. In this paper, we analyze whether main banks, an insensitive form of relationship banking, can moderate accounting conservatism.

There remains a research question of whether or not features of corporate governance or financial systems affect accounting conservatism stemming from agency conflicts, or asymmetric information under bank center economy, even if their effective monitoring can mitigate agency problems. We hypothesize that the Japanese main bank system can moderate the demand for accounting conservatism. As Aoki et al. (1994) and Shleifer and Vishny (1997) mentioned, market-oriented economies like the U.S. and the U.K. are different from bank-oriented economies like Japan. In a market-oriented economy, corporate governance systems essentially have strong legal protection for minority shareholders and monitoring roles of institutional investors. Accounting conservatism is especially demanded in firms with higher degrees of information asymmetry for their institutional investors (LaFond and 
Roychowdhury, 2008; Ramalingegowda and Yu, 2012). In a bank-oriented economy, main banks are expected to be effective monitors (Aoki, 1990; Sheard, 1994). Main banks are not only the largest lenders, but also have large shareholdings to maintain long-term relationships with their client firms (Aoki et al., 1994). These positions of main banks might enable them to monitor other stakeholders.

Lenders favor accounting conservatism because they enjoy its benefits in keeping with the positive accounting theory (Watts and Zimmerman, 1986). In the context of debt contracts, lenders are more interested in assuring the minimum amounts of net assets in borrowing firms to avoid problems pertaining to limited liability. Accordingly, they demand conservative accounting. This is because lenders cannot receive any additional wealth when a borrowing firm's net assets are above the face value of the debt (Watts, 2003a). The benefits of accounting conservatism to lenders have been summarized in several studies (Ahmed et al., 2002; Zhang, 2008). Firstly, conservatism improves the borrowers' debt ratings, and firms under severe debtholder-shareholder conflict tend to adopt more conservative accounting (Ahmed et al., 2002). Second, conservative financial reports are likely to trigger debt covenant violations. These accelerated covenant violations on the part of borrowers provide a chance for lenders to mitigate their downside risk in advance. Thus, conservatism of borrowers plays a role in signaling for lenders (Zhang, 2008).

However, no previous study has examined the relationship between the main bank and conservative accounting. We speculate that main banks do play a substitute role of signaling for other lenders instead of conservatism accounting of borrowers. Even in the U.S., lenders have to play an effective monitoring role in mitigating information asymmetry by using conservative accounting (Erkens et al., 2014). On the other hand, Japanese main banks have positions as both lenders and shareholders. Therefore, main banks are less likely to face an asymmetric downside risk, when compared to commercial banks in the U.S. In addition, main 
banks can gather private information on borrowers using the relationship banking technique (Aoki et al., 1994). Main bank systems are regarded as "a particular intense and close form of relationship banking” (Patrick, 1994). As a result, firms with main bank relationships might not face severe agency problems.

There is an additional empirical question to reveal the difference in delegated monitors between main banks and other banks having lending relationships with their client firms. This study focuses on the potential differences between main banks and other banks with lending ties alone. Japanese banks can gather private information on client firms through the lending relationship using “relational debt” (David et al., 2008; O’Brien et al., 2014). By using techniques of relationship lending, banks can gather detailed information on their client firms (Boot, 2000). As for relationships between lenders and borrowers, effective monitoring, such as relationship banking, can help mitigate the risk of lenders who may face their borrowers' limited liability problems.

In this paper, we examine conservative models similar to those of Erkens et al. (2014) to reveal an answer to this empirical question. The results of our paper are summarized as follows. First, we find that firms with main bank relationships have lower asymmetric timelines than firms without main bank relationships. Our finding implies that main banks would not demand accounting conservatism from the perspective of both lenders and effective shareholders. We can interpret that main banks can substitute the role of conservative accounting because they take on the role of delegated monitors. Second, we also investigate whether commercial banks, which only hold the position of lenders, demand accounting conservatism or not. We check the robustness to examine the analysis of restricted sample firms which have lending relationships. This suggests that commercial banks do not depend on private information through relational debt contracts.

This paper contributes to the literature on conservatism accounting and banking. First, 
this study analyzes the relationship between accounting conservatism and the main bank, to reveal who demands earlier recognition of loss value. Our findings show that the main bank system can significantly moderate accounting conservatism. Second, we also provide empirical evidence to contribute to banking literature, particularly to fields such as relationship banking. Our study is the first to reveal the role of main banks in relation to accounting conservatism. Our findings also reveal that only lending by banks does not affect management decisions of accounting conservatism.

The rest of this paper is organized as follows. The next section reviews the literature and develops our hypotheses. We then introduce our sample and discuss our estimation method. We then present our empirical results and additional analysis in the section that follows. Finally, we discuss and conclude the paper.

\section{Hypothesis Development}

\section{Conservatism, Information Asymmetry, and Agency Problem}

Accounting conservatism, in principle, functions so as to mitigate information asymmetry between insiders and outsiders. From the perspective of the agency theory, there are conflicts between shareholders and managers under separation of ownership and management in publicly listed companies. To mitigate potential conflicts among shareholders and managers, corporate governance is an important system that affects managerial decision making (Jensen and Meckling, 1976). Agency costs arising from information asymmetry are incurred by both shareholders and lenders of a firm.

There are two types of financial systems, namely, the Anglo-American model and the bank-based model (Aoki et al., 1994). The former is based on transaction finance, in that the security market plays an important role in financing. Thus, it is regarded as market-based finance, or capital market finance. The latter model depends on relationship finance that is 
constructed by repeated lending and close relationships between banks and clients. Previous studies on bank lending focus on the different roles of "relational debt" (also called "private loan”) and “transaction debt” (also called “market securities”; Boot, 2000; David et al., 2008; O’Brien et al., 2014). In financial systems, excluding the U.S., commercial banks play an important role as sources of finance for not only small and medium enterprises, but also for large listed firms (Patrick, 1994).

As for the relationship between the agency problem and accounting conservatism, institutional shareholders demand conservatism in dispersed ownership countries ${ }^{1}$ (Ramalingegowda and $\mathrm{Yu}, 2012$ ). In the U.S., institutional investors demand accounting conservatism in firms with higher degrees of information asymmetry. Accounting conservatism is highly investigated in firms where the separation of ownership and management is more pronounced (LaFond and Roychowdhury, 2008). In addition, conservative reporting occurs in firms with a higher degree of information asymmetry (Lafond and Watts, 2008). Greater institutional shareholdings are positively associated with conservative reporting in firms with higher information asymmetry (Ramalingegowda and Yu, 2012).

As lenders have incentives for minimizing agency cost by the late loss recognition of borrowing firms, they demand accounting conservatism. Debt contracts would also mitigate agency problems arising from debt relationships by transferring control rights from borrowers to lenders during bad conditions, through covenant violations (Black and Cox, 1976; Jensen and Meckling, 1976). As a result, accounting conservatism has been adopted to facilitate debt

\footnotetext{
${ }^{1}$ In family firms, Chen et al. (2014) show that conservative accounting is pronounced by founding CEO ownership because they have the incentive to reduce risk of potential litigation and agency costs consistent with Watts (2003a; 2003b). These studies imply that the one who demands conservatism might depend on the difference in the corporate ownership structure.
} 
contracts by triggering covenant violations through the recognition of accelerated loss (Watts, 2003a; Ball et al., 2008).

While debt contracting would be a driver of accounting conservatism, debt contracts cannot fully solve agency problems. Effective monitoring by lenders can moderate and solve agency problems between lenders and borrowers. Banks can gather detailed information on client firms by adopting relationship lending (Boot, 2000). In the U.S., relationship lending would help mitigate information asymmetry and substitute for the role of conservatism accounting (Erkens et al., 2014).

\section{Japanese Corporate Governance and Main Bank System}

Corporate governance in Japan is a bank-centered system, which is different from the market-oriented system in the U.S. One of the features of bank-centered systems is that banks play the role of main capital suppliers for firms (Biddle and Hilary, 2006). The other feature is a close relationship between bank and client firms through lending relationships (Aoki, 1990; Hoshi and Kashyap, 2001). Japanese main banks are defined as banks that lend the largest share of loans to client firms, and this is based on long-term relationships between the banks and the firms (Aoki et al., 1994). We introduce literature on Japanese corporate finance and several functions of the close relationship between them.

Main banks play an important role in monitoring their client firms and helping reduce principal-agency problems (Aoki, 1990). As Aoki et al. (1994) and Weistein and Yafeh (1998) mentioned, main banks are regarded as "delegated monitors" which is theoretically advocated by Diamond (1984). Bank lending or "relational debt" has a strong influence on management decisions such as R\&D investment (David et al., 2008). The turnover of top executives in a firm with bank relationships tend to be prompted, which is regarded as a disciplinary mechanism for executives (Kang and Shivdasani, 1995). As for executive 
compensation, executive incentive tends to be provided for firms with higher bank ownership (Sakawa et al., 2012). Thus, there might be a possibility that their information gathered through the monitoring activity is not necessarily restricted by financial reporting, but is also affected by the need to construct effective incentive compensation structures for their client firms.

Main banks do not bear the impact of severe conflicts that take place between shareholders and lenders. Debt holders have an asymmetric payoff related to net assets. This asymmetric payoff is problematic when borrowers face distress. Main banks are not only the largest lenders for client firms, but are also lenders for the large equity owners of the firms (Morck et al., 2000; Sakawa and Watanabel, 2014). Main banks may have the chance of acquiring additional payments, such as dividends, when projects of borrowing firms produce higher earnings. Therefore, main banks do not have incentive to transform wealth from lenders to shareholders because they are major shareholders of client firms (Prowse, 1990).

Main banks do not face severe problems as a result of information asymmetry between themselves and their client firms. At first, the equity ownership of main banks is regarded as a devise of the banks' commitment to their clients, to maintain their long-term relationships (Aoki et al., 1994). In Japan, firms which have relationship with a bank do not face severe liquidity problems when the firms make decisions on their investment (Hoshi et al., 1990; Hoshi et al., 1991). Even in the U.S., small firms with close ties to banks are able to access capital (Petersen and Rajan, 1994). Therefore, these long-term relationships are regarded as an important function of reducing asymmetric information problems between the main banks and their clients (Weistein and Yafeh, 1998).

Second, the main bank can gather private information in detail not only through lending activities but also through settlements accounting of their clients. Main banks have an information advantage vis-à-vis their client firms over other lending banks. Firms need to 
manage cash flow transactions, such as their checks and promissory bills (or Yakusoku Tegata in Japanese). Japanese firms tend to depend on receipts and payments in the settlements accounting of main banks for their cash flow (Aoki et al., 1994). Therefore, main banks can hold a financial position with respect to their client firms to check their cash flow.

Close relationships between main banks and their client firms are incentives for main banks to maintain their relationships. Sheard (1994) summarize the various business benefits of main banks, such as corporate bank deposit, bond issues, co-underwriter, and foreign exchange transactions ${ }^{2}$. In addition, main banks address large shares of foreign exchange business of clients' firms because clients maintain settlement accounts with main banks (Aoki et al., 1994).

On the other hand, main banks bear special obligation and responsibility when their client firms face financial distress (Sheard, 1994). Therefore, close relationships between banks and clients discourage banks from pursuing risky attitudes (Weistein and Yafeh, 1998). To maintain close relationships among banks and their clients, main banks extend the debt contracts of client firms to multiple beneficial business relationships. In this case, client firms are willing to submit their information to main banks, which is regarded as voluntary disclosure. If the firms give the main banks information related to their potential troubles, the main bank cannot abandon their duties and responsibilities (Aoki et al., 1994). Main banks play an important role of managing the financial position of client firms ${ }^{3}$.

\footnotetext{
${ }^{2}$ For example, main banks take a monotonic position when the client firms decide to issue their bonds.

${ }^{3}$ The roles of main banks differ based on financial conditions. Sheard (1994) summarizes their roles in the phase of financial distress of their client firms and shows the main banks' involvement in restructuring listed firms.
} 


\section{Main Bank System and Accounting Conservatism}

This paper analyzes the relationship between accounting conservatism and main banks in Japan. There are two main views of the relationship between main banks and accounting conservatism. One view is that main banks, being the largest lenders, tend to be more risk averse than other equity owners, because they need to maintain close ties with their client firms (Weistein and Yafeh, 1998). In principle, lenders are interested in protecting their debt by adopting conservatism accounting (Watts, 2003a). Thus, these close relationships between the banks and the firms would urge them to demand accounting conservatism.

The other view is that the main bank can moderate accounting conservatism, which is based on two paths. First, the Japanese main bank system can moderate principal-agent problems and the conflicts between lenders and shareholders. In addition, conflicts stemming from the asymmetric payoff are relatively small for main banks because the banks have a significant share of their own clients. Second, the central source of these agency problems is information asymmetry among lenders and borrowers ${ }^{4}$. Main bank systems moderate agency problems arising from asymmetric information between creditors and firms (Hoshi et al., 1990). Banks gather enough private information on the client firms by using the lending relationship or “relational debt” (David et al., 2008; O’Brien et al., 2014). The main bank is well informed about the client firms because of their duty and responsibility to be well informed. Thus, according to this view, main banks do not demand accounting conservatism.

To clarify the two possibilities, we consider the potential difference between main banks and commercial banks when it comes to their demand for conservative accounting. The

\footnotetext{
${ }^{4}$ In fact, Erkens et al. (2014) point out that "Borrower-lender information asymmetry is central to the agency problem of debt and, therefore, any monitoring mechanism that is effective in reducing this information asymmetry could potentially ameliorate the agency problem."
} 
former view suggests that the risk averse attitude of banks would promote the demand for conservative accounting. However, main banks would have several mechanisms to mitigate agency problems arising from debt contracts, which is different from the case of commercial banks. First, as Prowse (1990) mentioned, main banks are large equity holders and do not have concerns about asymmetric downside risk as lenders. Second, the main banks carefully monitor the client firms through their lending activities and by observing accounting settlements for both, their own interest and the other lenders' interests, as in the abovementioned second point of view ${ }^{5}$. Considering these two points, we speculate that main banks may play substitute roles of accounting conservatism. Therefore, we construct the following hypothesis related to accounting conservatism.

Hypothesis 1. Firms that have relationships with main banks adopt less conservative accounting than firms that do not have relationships with main banks.

\section{Data and Estimation Measure}

\section{Sample Selection and Variables}

We select data from non-financial firms listed in the Japanese stock exchange from 2007 to 2014 to analyze the relationship between non-financial listed firms and main banks. We drop all financial firms because we are interested in the relationships between main banks and client firms. The financial accounting data and corporate governance data including those on main banks are collected from the Nikkei Needs database, such as financial data and corporate governance evaluation system (CGES) data. To remove outliers, we drop the top or bottom $1 \%$ of market value deflated earnings. Our selected sample consists of 25,505 firm-

\footnotetext{
${ }^{5}$ Monitoring mechanisms of main banks reduce duplication of monitoring costs (Aoki et al., 1994).
} 
year observations.

We adopt a dummy variable (Main Bank Dummy or MBD) to analyze whether the main bank affects accounting conservatism or not. MBD equals 1 if the proportion of the largest lenders' shareholdings is positive and 0 otherwise. In addition, there might be a possibility that commercial banks that do not have stakes of client firms can take on a role to effectively monitor their client firms. Following a long-term relationship between main banks and client firms, banks without stakes in their client firms may not demand accounting conservatism.

\section{Empirical Strategy}

We define accounting conservatism as the asymmetric loss recognition coefficient model through Equation (1), following Basu (1997).

$$
\text { Earnings }_{i, t}=\alpha_{0}+\beta_{1} D_{R_{i, t}}+\beta_{2} \text { Ret }_{i, t}+\beta_{3} \operatorname{Ret}_{i, t} * D_{i, t}+I_{i, t}+\varepsilon_{i, t}
$$

Where:

Earnings $\mathrm{s}_{\mathrm{i}, \mathrm{t}}=$ Net income of firm $i$ in fiscal year $t$ divided by the beginning of the fiscal year market value of equity;

$\operatorname{Ret}_{i, \mathrm{t}}=$ Stock returns of firm $i$ in fiscal year $t$ over the fiscal year;

$\mathrm{DR}_{\mathrm{i}, \mathrm{t}}=$ An indicator variable that takes the value of 1 if Ret is negative and 0 otherwise;

We define three variables namely, Earnings, Ret, and $D R$, following Shuto and Takada (2010). In Equation (1), $\beta_{2}$ captures and measures the timeliness of earnings with respect to good news and $\beta_{3}$ captures accounting conservatism in terms of the asymmetric timeliness of earnings.

To analyze our empirical hypothesis, we expand the Basu model to incorporate the effect of both main bank relationships and bank lending. We estimate Equation (2) as 
follows:

$$
\begin{aligned}
\text { Earnings }_{\mathrm{i}, \mathrm{t}}=\alpha_{0} & +\beta_{1} \mathrm{DR}_{\mathrm{i}, \mathrm{t}}+\beta_{2} \text { Bank Relation }_{\mathrm{i}, \mathrm{t}-1}+\beta_{3} \mathrm{DR}_{\mathrm{i}, \mathrm{t}} * \text { Bank Relation }_{\mathrm{i}, \mathrm{t}-1} \\
& +\beta_{4} \text { Ret }_{\mathrm{i}, \mathrm{t}}+\beta_{5} \text { Ret }_{\mathrm{i}, \mathrm{t}} * \mathrm{DR}_{\mathrm{i}, \mathrm{t}}+\beta_{6} \text { Ret }_{\mathrm{i}, \mathrm{t}} * \text { Bank Relation }_{\mathrm{i}, \mathrm{t}-1} \\
& +\beta_{7} \text { Ret }_{\mathrm{i}, \mathrm{t}} * \mathrm{DR}_{\mathrm{i}, \mathrm{t}} * \text { Bank Relation }_{\mathrm{i}, \mathrm{t}-1}+\mathrm{ID}_{\mathrm{i}, \mathrm{t}}+\varepsilon_{\mathrm{i}, \mathrm{t}}
\end{aligned}
$$

Where:

Bank Relation ${ }_{i, t-1}=$ Main Bank Dummy $\left(\mathrm{MBD}_{\mathrm{i}, \mathrm{t}-1}\right)$ or Bank Lending $\mathrm{i}_{\mathrm{i}, \mathrm{t}-1}$;

$\mathrm{MBD}_{\mathrm{i}, \mathrm{t}-1}=\mathrm{An}$ indicator variable is equal to 1 if the proportion of main bank shareholdings of firm $\mathrm{j}$ at the end of year $\mathrm{t}-1$ are positive, otherwise it is 0 ;

Bank Lending $\mathrm{i}_{\mathrm{i}, \mathrm{t}-1}=$ The sum of all bank loans divided by the market value of firm $\mathrm{j}$ at the end of year $\mathrm{t}-1$;

$\mathrm{ID}_{\mathrm{i}, \mathrm{t}-1}=$ Industry fixed effects.

The other variables are defined in the same way as in Equation (1). If the coefficient $\beta_{7}$ is negative, firms with main bank relations $(M B D)$ or Bank Lending have lower asymmetric loss recognition than firms without them. Our estimations adopt cluster standard errors at the firm and year levels to control for residual dependence.

Next, we implement several control variables related to accounting conservatism. These variables are Market to Book ratio (MTB), financial leverage (Leverage), firm size $(M V)$, and the percentage of CEO ownership (CEO Ownership). MTB is adopted to control for the effects of the future asymmetric timelines of equity value (Roychowdhury and Watts, 2007). Financial leverage (Leverage) is controlled for the demand of accounting conservatism by debt holders. In addition, firm size $(M V)$ is also controlled because it is negatively correlated with asymmetric timeliness of earnings (LaFond and Watts, 2008). Finally, CEO ownership is controlled to capture agency problems between shareholders and managers 
(LaFond and Roychouwdhury, 2008). Our model adds several control variables into the Basu model as follows.

$$
\begin{aligned}
& \text { Earnings }_{i, \mathrm{t}}=\alpha_{0}+\beta_{1} \mathrm{DR}_{\mathrm{i}, \mathrm{t}}+\beta_{2} \mathrm{MD}_{\mathrm{i}, \mathrm{t}-1}+\beta_{3} \mathrm{DR}_{\mathrm{i}, \mathrm{t}} * \mathrm{MD}_{\mathrm{i}, \mathrm{t}-1} \\
& +\beta_{4} \operatorname{Ret}_{\mathrm{i}, \mathrm{t}}+\beta_{5} \operatorname{Ret}_{\mathrm{i}, \mathrm{t}} * \mathrm{DR}_{\mathrm{i}, \mathrm{t}}+\beta_{6} \text { Ret }_{\mathrm{i}, \mathrm{t}} * \mathrm{MD}_{\mathrm{i}, \mathrm{t}-1} \\
& +\beta_{7} \text { Ret }_{\mathrm{it}} * \mathrm{DR}_{\mathrm{it}} * \mathrm{MD}_{\mathrm{i}, \mathrm{t}-1}+\beta_{\mathrm{i}} \text { Control }_{\mathrm{i}, \mathrm{t}-1}+\beta_{\mathrm{i}} \mathrm{DR}_{\mathrm{it}} * \text { Control }_{\mathrm{i}, \mathrm{t}-1} \\
& +\beta_{\mathrm{i}} \operatorname{Ret}_{\mathrm{it}} * \text { Control }_{\mathrm{i}, \mathrm{t}-1}+\beta_{\mathrm{i}} \operatorname{Ret}_{\mathrm{it}} * \mathrm{DR}_{\mathrm{it}} * \text { Control }_{\mathrm{i}, \mathrm{t}-1}+\mathrm{ID}_{\mathrm{it}}+\varepsilon_{\mathrm{it}}
\end{aligned}
$$

$$
\begin{aligned}
& \text { Earnings }_{\mathrm{i}, \mathrm{t}}=\alpha_{0}+\beta_{1} \mathrm{DR}_{\mathrm{i}, \mathrm{t}}+\gamma_{2} \text { Bank Lending }_{\mathrm{i}, \mathrm{t}-1}+\gamma_{3} \mathrm{DR}_{\mathrm{i}, \mathrm{t}} * \text { Bank Lending }_{\mathrm{i}, \mathrm{t}-1} \\
& +\beta_{4} \text { Ret }_{\mathrm{i}, \mathrm{t}}+\beta_{5} \text { Ret }_{\mathrm{i}, \mathrm{t}} * \mathrm{DR}_{\mathrm{i}, \mathrm{t}}+\gamma_{6} \text { Ret }_{\mathrm{i}, \mathrm{t}} * \text { Bank Lending }_{\mathrm{i}, \mathrm{t}-1} \\
& +\gamma_{7} \text { Ret }_{\mathrm{it}} * \mathrm{DR}_{\mathrm{it}} * \text { Bank Lending }_{\mathrm{i}, \mathrm{t}-1}+\beta_{\mathrm{i}} \text { Control }_{\mathrm{i}, \mathrm{t}-1}+\beta_{\mathrm{i}} \mathrm{DR}_{\mathrm{it}} * \text { Control }_{\mathrm{i}, \mathrm{t}-1} \\
& +\beta_{\mathrm{i}} \text { Ret }_{\mathrm{it}} * \text { Control }_{\mathrm{i}, \mathrm{t}-1}+\beta_{\mathrm{i}} \text { Ret }_{\mathrm{it}} * \mathrm{DR}_{\mathrm{it}} * \text { Control }_{\mathrm{i}, \mathrm{t}-1}+\mathrm{ID}_{\mathrm{it}}+\varepsilon_{\mathrm{it}}
\end{aligned}
$$

Where

$\mathrm{MTB}_{\mathrm{j}, \mathrm{t}-1}=$ Market to Book ratio of firm $\mathrm{j}$ at the end of year $\mathrm{t}-1$;

Leverage $_{\mathrm{j}, \mathrm{t}-1}=$ Financial leverage of firm $\mathrm{j}$ at the end of year $\mathrm{t}-1$;

$\mathrm{MV}_{\mathrm{j}, \mathrm{t}-1}=$ Market value of equity of firm $\mathrm{j}$ at the end of year $\mathrm{t}-1$;

CEO Ownership $\mathrm{j}_{\mathrm{j}, \mathrm{t}-1}=$ The percentage of CEO ownership of firm $\mathrm{j}$ at the end of year $\mathrm{t}-1$.

\section{Results}

\section{Descriptive Statistics}

Our descriptive statistics and correlation matrix, and the sample are reported in Panels A and B in Table 1. In Panel A, the average of earnings is 0.034 , which is smaller than the average earnings of U.S. firms as reported by Erkens et al. (2014). The mean of stock returns (RET) indicates -0.015 which suggests that Japanese firms suffered from global financial crisis. The mean of DR (negative return dummy) also occupies more than 0.5 which shows 
the same tendency as seen in previous studies such as Shuto and Takada (2010). We find 8,849 firm-year observations (about $35.3 \%$ ) which have relationships with main banks. It appears that these relationships are still maintained for more than $1 / 3$ of the total number of Japanese listed firms.

Table 1 goes about here

As for Pearson's correlation matrix in Panel B of Table 1, we can find that earnings are positively correlated with RET and negatively with DR. This implies that reported earnings include a part of information that is consistent with previous studies such as Basu (1997) and LaFond and Roychowdhury (2008). In addition, bank lending dummy is negatively correlated with MBD. This implies that there are conflicts among banks as lenders and shareholders.

We compare the differences between sample firms with and without MBD. Panel C of Table 1 reports the results of the mean difference $t$ test. In Panel C, we find that firms with MBD have significantly higher earnings, which is a higher indicator of negative stock returns (DR). This suggests that conservatism accounting might be mitigated in firms with MBD. In addition, we also find higher bank lending ratio and higher leverage. These means that firms with MBD tend to rely on debt financing more than firms without MBD. We also find that MTB and firm size with MBD are significantly lower, implying that firms with lower growth opportunities and smaller sizes tend to be monitored by main banks. Finally, CEO ownership is significantly lower for firms with MBD. This means that the main bank would be helpful to reduce agency conflicts between shareholders and managers. 


\section{Regression Results}

We first test whether MBD firms adopt less conservative accounting than non-MBD firms or not, using whole samples of our analysis. This result is reported in Table 2, which aims to reveal whether or not the degree of accounting conservatism is differently observed between MBD and non-MBD firms. Our estimated models adopt cluster standard errors at the firm and year levels to control for residual dependence. To remove outliers, we drop the top $1 \%$ of the absolute standardized residuals.

Table 2 goes about here

In Table 2 , we find that the coefficient $\left(\beta_{5}\right)$ is significantly positive and accounting conservatism is observed for all six estimated models. As for the role of main banks, we find that the coefficient of MBD $\left(\beta_{7}\right)$ is significantly negative in Models (1), (2), and (3). This implies that firms with MBD use less accounting conservatism than firms without, which is consistent with Hypothesis 1. On the other hand, Table 2 shows that the coefficient of bank lending relationship $\left(\gamma_{7}\right)$ is not significant in Models (4), (5), and (6).

Next, we check whether or not bank lending relationships are negative to accounting conservatism using the alternative models in Table 3. First, we insert both MBD and Bank Lending into the estimation models to adopt all samples in Models (1), (2), and (3). Furthermore, we focus on firms with bank lending relationships in Models (4), (5), and (6) to check the robustness of our results. Using Table 3 , we also find that the coefficient $\left(\beta_{5}\right)$ is significantly positive, implying accounting conservatism for not only all firms, but also firms with bank lending relationships. We can find that coefficient $\left(\beta_{7}\right)$ is also significant and negative in all models, which is consistent with Hypothesis 1 . The coefficient $\left(\gamma_{7}\right)$ is not 
significant to accounting conservatism. Therefore, we can conclude that main banks, as both lenders and shareholders, matter for decreasing accounting conservatism.

Table 3 goes about here

\section{Robustness of Results}

To control for the impact of covariates on the dependent variable, we use a propensity score matching (PSM) to examine the effectiveness of main bank relationships. We adopt $M T B$ as a proxy for the understatement of net assets. We include financial leverage (Leverage) to control for demand for conservatism as debt holders. Firm size is controlled by the logarithm of total assets (In(Assets)). We adopt stock return volatility (Volatility) to control for firm risk. We measure the amount of free cash-flow (Free Cash) as cash flow from operating activities and investing activities divided by total assets. Bank lending (Bank Lending) is the sum of all bank loans divided by the market value of the firm (O'Brien et al., 2014).

In Table 4, we show the results of the logit models to derive the PSM. The dependent variables is the dummy of MBD firms. This tables indicates that MBD firms tend to be smaller and have higher debt ratio than non-MBD firms. A large amount of main bank lending is also investigated in MBD firms. In addition, free cash flow is less used for MBD firms, implying that main bank monitors help reduce managerial free cash flow. Overall, the controlling variables might be potentially important factors.

Table 4 goes about here 
To control for impact of covariates on the dependent variable, we use PSM. The final sample of score matching is 16,492 firm-year observations, which consist of 8,246 from MBD firms and 8,246 from non-MBD firms. Using PSM, we confirm the robustness of our results in Table 5. In Table 5, the negative coefficient $\beta_{7}$ is also significant and negative, supporting Hypothesis 1. We confirm the supporting evidence that lower asymmetric timelines arise from both gain and loss recognition in Table 5. Therefore, we can conclude that our estimated results are robust after using the PSM method.

Table 5 goes about here

\section{Discussion and Conclusions}

In a market-oriented economy like the U.S., the process of monitoring through lending mitigates lenders' demand for accounting conservatism (Erkens et al., 2014). On the other hand, no previous study reveals the relationship between accounting conservatism and monitoring by lending relationships, which would be a typical analogy for main bank systems in the bank-dominated corporate governance system in Japan. Therefore, our research question is to clarify whether or not main bank monitoring would substitute accounting conservatism. To investigate this, we examine how relationships with main banks influence the demand for conservative accounting in Japanese corporations.

We empirically reveal that firms with relationships with main banks adopt less conservative accounting. The robustness of our findings is confirmed by the PSM method. This is due to the effective monitoring of main banks, which can reduce information asymmetry and agency problems. Main banks can gather private information on borrowing 
firms through their monitoring activity (Hoshi et al., 1991). Different from market-oriented system like in the U.S., Japanese main banks, as both lenders and shareholders, do not face asymmetric payoff problems, and do not necessarily demand accounting conservatism. This finding would be interpreted to mean that main banks play a role in effective monitoring and do not demand conservative accounting.

We focus on whether or not main banks and banks with only lending relationships demand accounting conservatism. From the view of lenders, they might demand accounting conservatism to mitigate agency problems. We cannot gain significant results for firms connected to commercial banks without stakes. This implies that commercial banks in Japan might not adopt less accounting conservatism, different from main banks. Main banks play the role of monitors from the viewpoint of both, lenders and shareholders, which differs from commercial banks without stakes. Therefore, monitoring of banks which only have lending relationships does not substitute for conservative accounting in a bank-dominated economy.

This paper makes several contributions. First, our findings develop the role of agency theory related to bank monitoring mechanisms. Our findings reveal that monitoring of main banks would be strong enough to substitute for accounting conservatism, but the other lending banks may demand accounting conservatism because their monitoring does not have enough to substitute for accounting conservatism. This conclusion can contribute to understanding who demands accounting conservatism to mitigate agency problems in bankdominated corporate governance systems like in Japan. Second, we also provide empirical evidence to contribute banking literature such as main banks and relationship banking. Our findings suggest that relationship banking can gather private information on borrowers using their lending technology. This suggests that the role of main banks, in being delegated monitors, is supported by the close relationship between them and their client firms using relationship banking techniques. 
There are several limitations in our study. First, our study only focuses on the role of main banks in monitoring large Japanese listed firms. Smaller firms are more likely to depend on their banking relationships because they face difficulties in raising capital through financial markets. Thus, monitoring activity of lending banks would be stronger for these relatively smaller client firms, and substitute for accounting conservatism. Thus, the potential avenue for future research is to examine the relationship between main banks or lending banks and conservative accounting in smaller and medium sized firms. Second, the implication of this paper cannot be applied to large corporations in other countries because corporate governance features are different among different national bundles (Zattoni et al., 2009). Thus, there might be possibilities that relationship banking would not play sufficient substitute roles for accounting conservatism in other countries. To understand this, our future task would be to enlarge our knowledge of various corporate governance mechanisms in mitigating agency problems arising from debt contracts. 


\section{References}

Ahmed, A., Billings, B., Morton, R., \& Harris, M. (2002). The role of accounting conservatism in mitigating bondholder-shareholder conflict over dividend policy and in reducing debt cost. The Accounting Review, 77 (4), 867-890.

Aoki, M. (1990). Toward an economic model of the Japanese firm. Journal of Economic Literature, 28 (1), 1-27.

Aoki, M., Patrick, H., \& Sheard, P. (1994). The Japanese main bank system: An introductory review. In M. Aoki, \& H. Patrick (Eds.) The Japanese Main Bank System: Its Relevance for Developing and Transforming Economies: (pp. 1-50), Oxford: Oxford University Press.

Aguilera, R. V., Desender, K., Bednar, M. K., \& Lee, J. H. (2015). Connecting the dots: Bringing external corporate governance into the corporate governance puzzle. Academy of Management Annals, 9 (1), 483-573.

Ball, R., Robin, A., \& Sadka, G. (2008). Is financial reporting shaped by equity markets or by debt markets? An international study of timeliness and conservatism. Review of Accounting Studies, 13 (2-3), 168-205.

Basu, S. (1997). The conservatism principle and the asymmetric timeliness of earnings. Journal of Accounting and Economics, 24 (1), 3-37.

Biddle, G. C., \& Hilary, G. (2006). Accounting quality and firm-level capital investment. The Accounting Review, 81 (5), 963-982.

Black, F., \& Cox, J. C. (1976). Valuing corporate securities: Some effects of bond indenture provisions, Journal of Finance, 31 (2), 351-367.

Boot, A. (2000). Relationship banking: What do we know? Journal of Financial Intermediation, 9, 7-25.

Chen, S., Chen, X., \& Cheng, Q. (2014). Conservatism and equity ownership of the founding 
family. European Accounting Review, 23 (3), 403-430.

David, P., O'Brien, J. P., \& Yoshikawa, T. (2008). The Implications of debt heterogeneity for R\&D investment and firm performance. Academy of Management Journal, 51 (1), 165181.

Erkens, D. H., Subramanyam, K. R., \& Zhang, J. (2014). Affiliated Banker on Board and Conservative Accounting. The Accounting Review, 89 (5), 1703-1728.

Hoshi, T., \& Kashyap, A. (2001). Corporate financing and governance in Japan. Cambridge, MA: MIT Press.

Hoshi, T., Kashyap, A., \& Scharfstein, D. (1990). The role of banks in reducing the costs of financial distress in Japan. Journal of Financial Economics, 27 (1), 67-88.

Hoshi, T., Kashyap, A., \& Scharfstein, D. (1991). Corporate structure, liquidity, and investment: Evidence from Japanese industrial groups. Quarterly Journal of Economics, 106 (1), 33-60.

Jensen, M. C., \& Meckling, W. (1976). Theory of the firm: managerial behavior, agency costs, and ownership structure. Journal of Financial Economics, 3 (4), 305-360

Kang, J. K., \& Shivdasani, A. (1995). Firm performance, corporate governance, and top executive turnover in Japan. Journal of Financial Economics, 38 (1), 29-58.

LaFond, R., \& Roychowdhury, S. (2008). Managerial ownership and accounting conservatism. Journal of Accounting Research, 46 (1), 101-135.

LaFond, R., \& Watts, R. L. (2008). The information role of conservatism. The Accounting Review, 83 (2), 447-478.

Morck, R., Nakamura, M., \& Shivdasani, A. (2000). Banks, ownership structure, and firm value in Japan. Journal of Business, 73 (4), 539-567.

O’Brien, J., David, P., Yoshikawa, T., \& Delios, A. (2014). How capital structure influences diversification performance: A transaction cost perspective. Strategic Management 
Journal, 35 (7), 1013-1031.

Patrick, H. (1994). The relevance of Japanese finance and its main bank system. In M. Aoki, \& H. Patrick (Eds.) The Japanese Main Bank System: Its Relevancy for Developing and Transforming Economies: (pp. 353-408), Oxford: Oxford University Press.

Petersen, M., \& Rajan, R. (1994). The benefits of lending relationships: Evidence from small business data. Journal of Finance, 49 (1), 3-37.

Prowse, S. D. (1990). Institutional investment patterns and corporate financial behavior in the US and Japan. Journal of Financial Economics, 27 (1), 43-66.

Ramalingegowda, S., \& Yu, Y. (2012). Institutional ownership and conservatism. Journal of Accounting and Economics, 53 (1-2), 98-114.

Roychowdhury, S., \& Watts, R. (2007). Asymmetric timeliness of earnings, market-to-book and conservatism in financial reporting. Journal of Accounting and Economics, 44 (1-2), $2-31$.

Sakawa, H., Moriyama, K., \& Watanabel, N. (2012). Relation between top executive compensation structure and corporate governance: Evidence from Japanese public disclosed data. Corporate Governance: An International Review, 20 (6), 593-608

Sakawa, H., Ubukata, M., \& Watanabel, N. (2014). Market liquidity and bank-dominated corporate governance: Evidence from Japan. International Review of Economics and Finance, 31, 1-11

Sheard, P. (1994). The main bank and the governance of financial distress. In M. Aoki, \& H. Patrick (Eds.) The Japanese Main Bank System: Its Relevancy for Developing and Transforming Economies: (pp. 188-230), Oxford: Oxford University Press.

Shuto, A., \& Takada, T. (2010). Managerial ownership and accounting conservatism in Japan: A test of management entrenchment effect. Journal of Business Finance and Accounting, 37 (7-8), 815-840. 
Watts, R. (2003a). Conservatism in accounting part I: explanations and implications. Accounting Horizons, 17 (3), 207-221.

Watts, R. (2003b). Conservatism in accounting part II: evidence and research opportunities. Accounting Horizons, 17 (4), 287-301.

Watts, R., \& Zimmerman, J. (1986). Positive Accounting Theory. Englewood Cliffs, NJ: Prentice-Hall.

Weinstein, D. E., \& Yafeh, Y. (1998). On the costs of a bank-centered financial system: Evidence from the changing main bank relations in Japan. Journal of Finance, 53 (2), 635772.

Zattoni, A., Pedersen, T., \& Kumar, V. (2009). The performance of group-affiliated firms during institutional transition: A longitudinal study of Indian firms. Corporate Governance: An International Review, 17 (4), 510-523.

Zhang, J. (2008). The contracting benefits of accounting conservatism to lenders and borrowers. Journal of Accounting and Economics, 45 (1), 27-54. 


\section{Appendix A}

Table A1: Variable definitions

\begin{tabular}{|c|c|}
\hline Variable & Definition \\
\hline Earnings & $\begin{array}{l}\text { Net income divided by the beginning of fiscal year market value of } \\
\text { equity }\end{array}$ \\
\hline DR & $\begin{array}{l}\text { Indicator variable that takes the value of } 1 \text { if Stock returns (Ret) are } \\
\text { negative, and } 0 \text { otherwise }\end{array}$ \\
\hline Ret & Stock returns over the fiscal year \\
\hline MBD & $\begin{array}{l}\text { It is equal to } 1 \text { if the proportion of main bank shareholdings are } \\
\text { positive, otherwise it is } 0\end{array}$ \\
\hline Bank Lending & The sum of all bank loans divided by the market value of the firm \\
\hline MTB & The market value divided by book value of capital of the firm \\
\hline Leverage & The sum of debt divided by total assets \\
\hline Firm Size & Logarithm of the market value of the firm \\
\hline CEO Ownership & The percentage of CEO ownership \\
\hline Ln(Assets) & Logarithm of total assets \\
\hline Volatility & Stock volatility during three years \\
\hline Volatility^2 & Square of stock volatility (Volatility) during three years \\
\hline Free Cash & $\begin{array}{l}\text { Cash flows from operating activities and investing activities divided } \\
\text { by total assets }\end{array}$ \\
\hline
\end{tabular}




\section{Table 1:}

Panel A. Descriptive Statistics

\begin{tabular}{lrrrrr}
\hline Variable & Mean & Std. Dev. & Q1 & Median & \multicolumn{1}{c}{ Q3 } \\
\hline Earnings & 0.033 & 0.140 & 0.016 & 0.052 & 0.092 \\
DR & 0.525 & 0.499 & 0.000 & 1.000 & 1.000 \\
Ret & -0.020 & 0.173 & -0.102 & -0.008 & 0.069 \\
MBD & 0.353 & 0.478 & 0.000 & 0.000 & 1.000 \\
Bank Lending & 0.560 & 1.093 & 0.000 & 0.160 & 0.674 \\
Leverage & 49.842 & 20.835 & 33.580 & 50.600 & 66.080 \\
MTB & 1.526 & 7.406 & 0.603 & 0.919 & 1.505 \\
CE0 Ownership & 7.050 & 12.219 & 0.072 & 0.768 & 8.869 \\
Firm Size & 103393 & 507426 & 3867.0 & 10959.0 & 40295.0 \\
\hline
\end{tabular}

Notes: $N=25,055$. Descriptive statistics are based on the data from non-financial firms listed at the Japanese stock exchange from 2007 to 2014. See Appendix A for variable definitions.

Panel B. Correlation Coefficients

\begin{tabular}{|c|c|c|c|c|c|c|c|c|}
\hline Variable & (1) & (2) & (3) & (4) & (5) & (6) & (7) & (8) \\
\hline \multicolumn{9}{|l|}{ 1. Earnings } \\
\hline 2. DR & $-0.259 *$ & & & & & & & \\
\hline 3. Ret & $0.334 *$ & $-0.704 *$ & & & & & & \\
\hline 4. MBD & 0.027 * & $0.020 *$ & 0.001 & & & & & \\
\hline 5. Bank Lending & $-0.059 *$ & $-0.063 *$ & $0.077 *$ & $0.247 *$ & & & & \\
\hline 6.Leverage & -0.009 & 0.035 * & $-0.032 *$ & $0.280 *$ & $0.495 *$ & & & \\
\hline 7. MTB & $-0.017 *$ & $0.044 *$ & $-0.071 *$ & $-0.030 *$ & $-0.022 *$ & $0.060 *$ & & \\
\hline 8. CEO Ownership & -0.007 & 0.018 * & $-0.038 *$ & $-0.113 *$ & $0.026 *$ & $-0.050 *$ & 0.035 * & \\
\hline 9. Firm Size & $0.017^{*}$ & 0.006 & -0.010 & $-0.077 *$ & $-0.069 *$ & $0.020 *$ & $0.013^{*}$ & -0.091 * \\
\hline
\end{tabular}

Notes: $N=25,055$. See Appendix A for variable definitions. * indicate significance at the 5\% level. 
Panel C. Mean Difference between MBD and Non-MBD

\begin{tabular}{lrrrl}
\hline & \multicolumn{3}{c}{ MBD (Mean) } & \\
Variable & \multicolumn{1}{c}{ No } & \multicolumn{1}{c}{ Yes } & \multicolumn{1}{c}{ Difference } \\
\hline Earnings & 0.030 & 0.038 & -0.008 & $* * *$ \\
DR & 0.517 & 0.538 & -0.021 & $* *$ \\
Ret & -0.021 & -0.020 & 0.000 & \\
Bank Lending & 0.361 & 0.925 & -0.564 & $* * *$ \\
Leverage & 45.533 & 57.734 & -12.201 & $* * *$ \\
MTB & 1.691 & 1.223 & 0.467 & $* * *$ \\
CEO Ownership & 8.070 & 5.181 & 2.889 & $* * *$ \\
Firm Size & 132074 & 50865 & 81209 & $* * *$ \\
Observations & 16206 & 8849 & & \\
\hline
\end{tabular}

Notes: $\mathrm{N}=25,055$. See Appendix A for variable definitions. ***, **, and * indicate significance at the $0.1 \%, 1 \%$, and $5 \%$ levels. 
Table 2: Conservatism and Main Bank Relation (All data)

$$
\begin{aligned}
& \text { Earnings }_{\mathrm{i}, \mathrm{t}}=\alpha_{0}+\beta_{1} \mathrm{DR}_{\mathrm{i}, \mathrm{t}}+\beta_{2} \text { Bank Relation }_{\mathrm{i}, \mathrm{t}-1}+\beta_{3} \mathrm{DR}_{\mathrm{i}, \mathrm{t}} * \text { Bank Relation }_{\mathrm{i}, \mathrm{t}-1} \\
& +\beta_{4} \operatorname{Ret}_{i, \mathrm{t}}+\beta_{5} \text { Ret }_{i, \mathrm{t}} * \mathrm{DR}_{\mathrm{i}, \mathrm{t}}+\beta_{6} \text { Ret }_{\mathrm{i}, \mathrm{t}} * \text { Bank Relation }_{\mathrm{i}, \mathrm{t}-1} \\
& +\beta_{7} \text { Ret }_{\text {it }} * \mathrm{DR}_{\mathrm{it}} * \text { Bank Relation }_{\mathrm{i}, \mathrm{t}-1}+\beta_{\mathrm{i}} \text { Control }_{\mathrm{i}, \mathrm{t}-1}+\beta_{\mathrm{i}} \mathrm{DR}_{\mathrm{it}} * \text { Control }_{\mathrm{i}, \mathrm{t}-1} \\
& +\beta_{\mathrm{i}} \text { Ret }_{\text {it }} * \text { Control }_{\mathrm{i}, \mathrm{t}-1}+\beta_{\mathrm{i}} \text { Ret }_{\mathrm{it}} * \mathrm{DR}_{\mathrm{it}} * \text { Control }_{\mathrm{i}, \mathrm{t}-1}+\mathrm{ID}_{\mathrm{it}}+\varepsilon_{\mathrm{it}} \\
& +\beta_{4} \text { Ret }_{i, t}+\beta_{5} \text { Ret }_{i, t} * \text { DR }_{i, t}+\gamma_{6} \text { Ret }_{i, t} * \text { Bank Lending }_{i, t-1} \\
& +\gamma_{7} \text { Ret }_{i \mathrm{t}} * \mathrm{DR}_{\mathrm{it}} * \text { Bank Lending }_{\mathrm{i}, \mathrm{t}-1}+\beta_{\mathrm{i}} \text { Control }_{\mathrm{i}, \mathrm{t}-1}+\beta_{\mathrm{i}} \mathrm{DR}_{\mathrm{it}} * \text { Control }_{\mathrm{i}, \mathrm{t}-1} \\
& +\beta_{\mathrm{i}} \text { Ret }_{\text {it }} * \text { Control }_{\mathrm{i}, \mathrm{t}-1}+\beta_{\mathrm{i}} \text { Ret }_{\mathrm{it}} * \mathrm{DR}_{\mathrm{it}} * \text { Control }_{\mathrm{i}, \mathrm{t}-1}+\mathrm{ID}_{\mathrm{it}}+\varepsilon_{\mathrm{it}}
\end{aligned}
$$

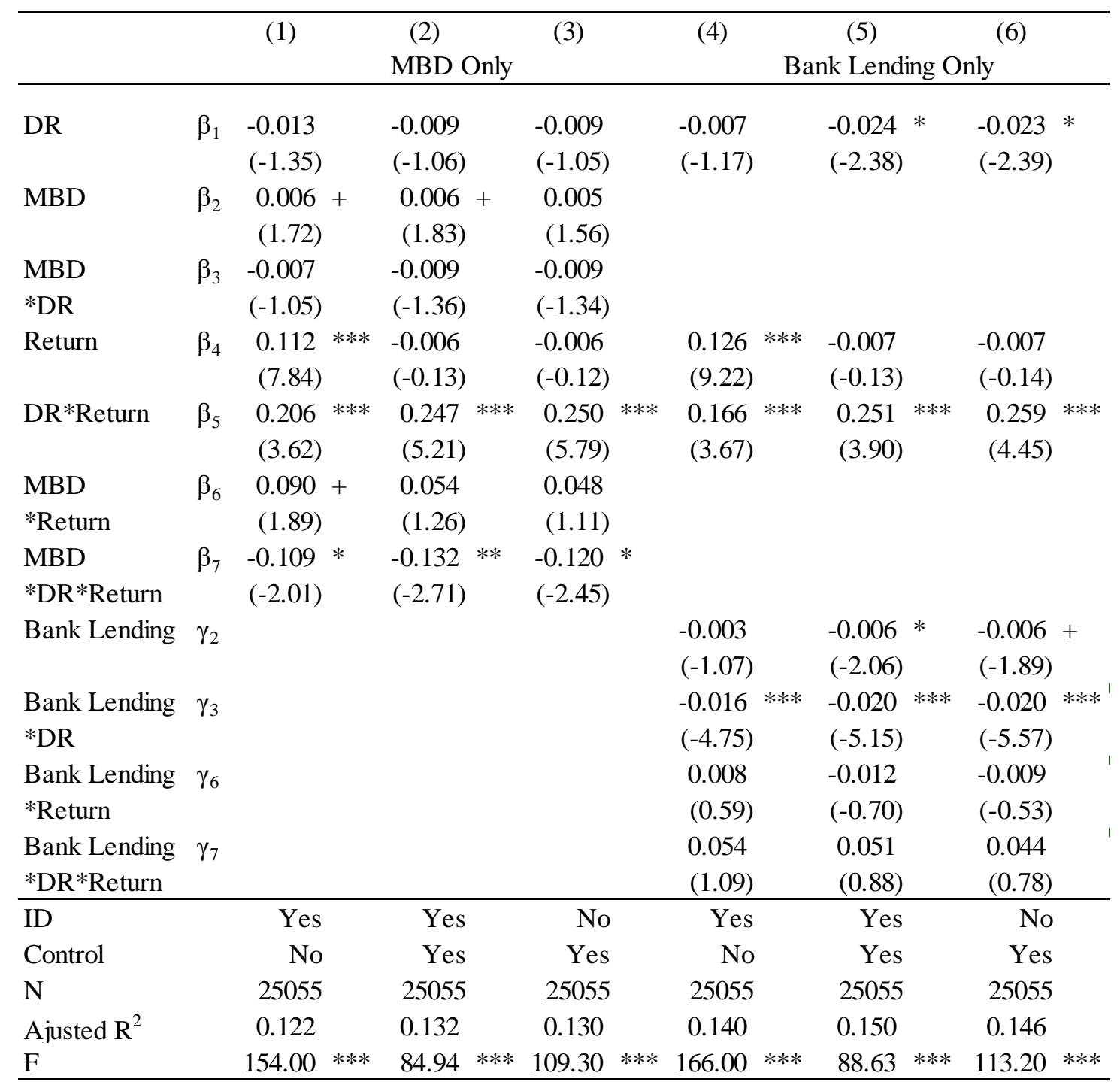

This table presents the results of a regression model that examines the relationship between a main bank and accounting conservatism using the Basu model. Estimated data is based on all samples. We cluster standard errors at the firm and year levels. T-values are presented in parentheses. The results of industry dummies and control variables are not reported. See Appendix A for variable definitions. $* * *, * *$, and $*$ indicate significance at the $0.1 \%, 1 \%$, and $5 \%$ levels. 
Table 3: Conservatism and Main Bank Relationship

$$
\begin{aligned}
& \text { Earnings }_{\mathrm{i}, \mathrm{t}}=\alpha_{0}+\beta_{1} \text { DR }_{\mathrm{i}, \mathrm{t}}+\beta_{2} \text { Bank Relation }_{\mathrm{i}, \mathrm{t}-1}+\beta_{3} \mathrm{DR}_{\mathrm{i}, \mathrm{t}} * \text { Bank Relation }_{\mathrm{i}, \mathrm{t}-1} \\
& \quad+\beta_{4} \text { Ret }_{\mathrm{i}, \mathrm{t}}+\beta_{5} \text { Ret }_{\mathrm{i}, \mathrm{t}} * \mathrm{DR}_{\mathrm{i}, \mathrm{t}}+\beta_{6} \text { Ret }_{\mathrm{i}, \mathrm{t}} * \text { Bank Relation }_{\mathrm{i}, \mathrm{t}-1} \\
& \quad+\beta_{7} \text { Ret }_{\mathrm{it}} * \mathrm{DR}_{\mathrm{it}} * \text { Bank Relation }_{\mathrm{i}, \mathrm{t}-1}+\gamma_{2} \text { Bank Lending }_{\mathrm{i}, \mathrm{t}-1} \\
& \quad+\gamma_{3} \mathrm{DR}_{\mathrm{i}, \mathrm{t}} * \text { Bank Lending }_{\mathrm{i}, \mathrm{t}-1}+\gamma_{6} \text { Ret }_{\mathrm{i}, \mathrm{t}} * \text { Bank Lending }_{\mathrm{i}, \mathrm{t}-1} \\
& \quad+\gamma_{7} \text { Ret }_{\mathrm{it}} * \mathrm{DR}_{\mathrm{it}} * \text { Bank Lending }_{\mathrm{i}, \mathrm{t}-1}+\beta_{\mathrm{i}} \text { Control }_{\mathrm{i}, \mathrm{t}-1}+\beta_{\mathrm{i}} \mathrm{DR}_{\mathrm{it}} * \text { Control }_{\mathrm{i}, \mathrm{t}-1} \\
& \quad+\beta_{\mathrm{i}} \text { Ret }_{\mathrm{it}} * \text { Control }_{\mathrm{i}, \mathrm{t}-1}+\beta_{\mathrm{i}} \text { Ret }_{\mathrm{it}} * \mathrm{DR}_{\mathrm{it}} * \text { Control }_{\mathrm{i}, \mathrm{t}-1}+\mathrm{ID}_{\mathrm{it}}+\varepsilon_{\mathrm{it}}
\end{aligned}
$$

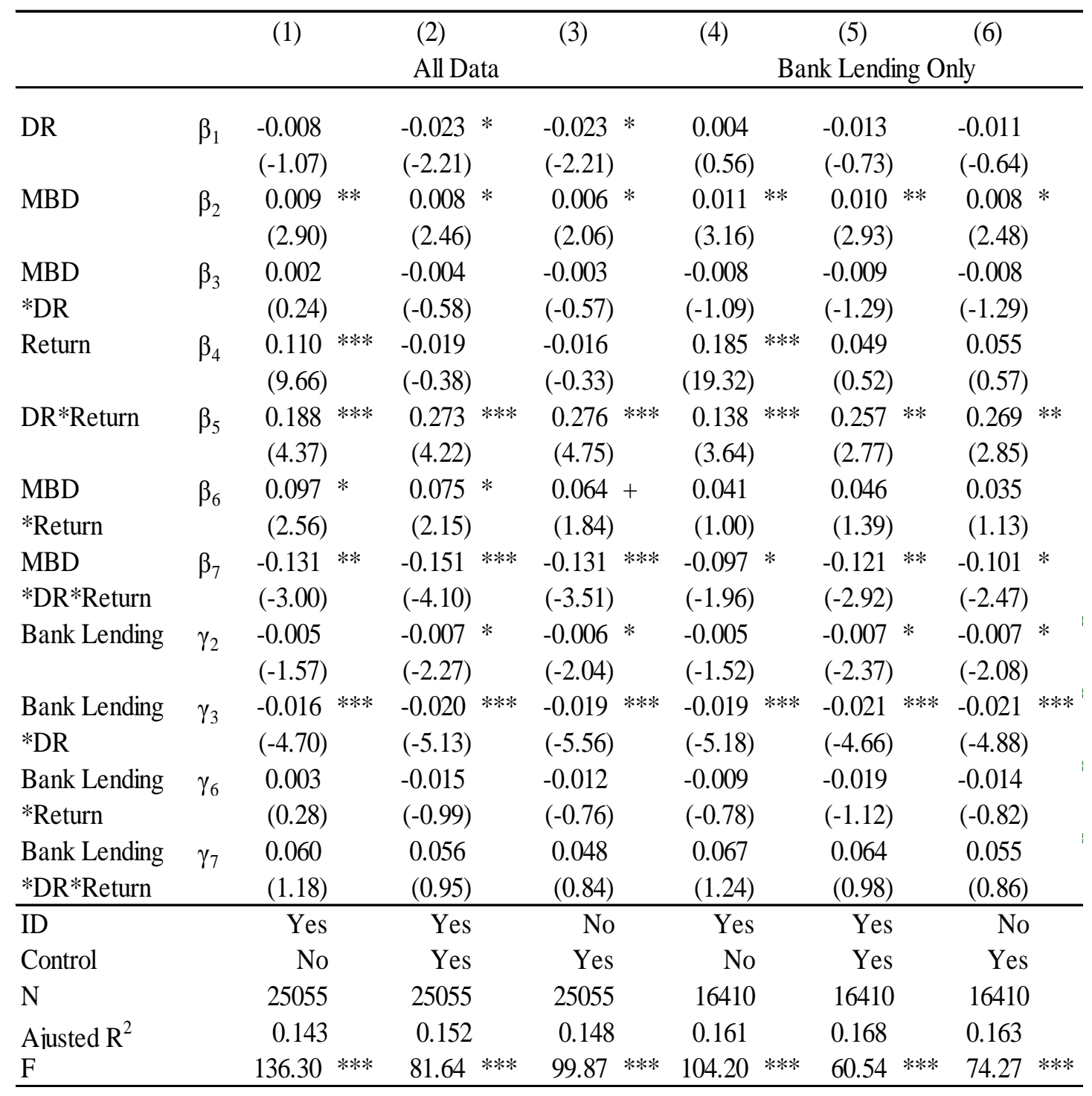

This table presents the results of a regression model that examines the relationship between a main bank and accounting conservatism using the Basu model. Estimated data is based on all firms in Models (1)-(3) and firms with bank lending relationships in Models (4)-(6). We cluster the standard errors at the firm and year levels. T-values are presented in parentheses. See Appendix A for variable definitions. The results of industry dummies and control variables are not reported. ***, **, and * indicate significance at the $0.1 \%, 1 \%$, and the $5 \%$ levels. 
Table 4: Logit Models Predicting on MBD

\begin{tabular}{lc}
\hline & MBD \\
\hline MTB & $-0.117 * * *$ \\
Leverage & $(-7.55)$ \\
& $0.026 * * *$ \\
Ln(Assets) & $(23.00)$ \\
& $-0.192 * * *$ \\
Volatility & $(-17.67)$ \\
& -0.033 \\
Volatility^2 & $(-0.49)$ \\
& $-0.048 * * *$ \\
Free Cash & $(-4.68)$ \\
& $-2.213 * * *$ \\
Bank Lending & $(-14.67)$ \\
& $0.329 * * *$ \\
Constant & $(16.60)$ \\
& 0.040 \\
Industry & $(0.24)$ \\
Year & Yes \\
\hline N & Yes \\
Pseudo R2 & 24012 \\
\hline This & 0.1507
\end{tabular}

This table presents the estimated results of a logit model to reveal the determinants of the main bank relationship. $T$-statistics are shown in parentheses. See Appendix A for variable definitions. The results of industry dummies and year dummies are not reported. ***, **, and * indicate significance at the $0.1 \%, 1 \%$, and $5 \%$ levels. 
Table 5: Conservatism and Main Bank Relationships (Using propensity-matched samples)

\begin{tabular}{lll}
\hline & $(1)$ & $(2)$ \\
\hline$\beta_{1}$ & $-0.011 *$ & $-0.010 *$ \\
& $(-2.56)$ & $(-2.41)$ \\
$\beta_{2}$ & -0.002 & -0.002 \\
& $(-0.44)$ & $(-0.40)$ \\
$\beta_{3}$ & -0.007 & -0.007 \\
& $(-1.14)$ & $(-1.19)$ \\
$\beta_{4}$ & $0.191 * * *$ & $0.196 * * *$ \\
& $(6.48)$ & $(6.63)$ \\
$\beta_{5}$ & $0.264 * * *$ & $0.258 * * *$ \\
& $(6.84)$ & $(6.62)$ \\
$\beta_{6}$ & 0.017 & 0.015 \\
& $(0.39)$ & $(0.36)$ \\
$\beta_{7}$ & $-0.154 * *$ & $-0.154 * *$ \\
& $(-2.79)$ & $(-2.79)$ \\
\hline Industry & No & Yes \\
$\mathrm{N}$ & 16492 & 16492 \\
Ajusted $\mathrm{R}^{2}$ & 0.139 & 0.141 \\
$\mathrm{~F}$ & $141.2 * * *$ & $288.7 * * *$ \\
\hline
\end{tabular}

This table presents the results of a regression model that examines the relationship between a main bank and accounting conservatism using the Basu model. Estimated data is based on all samples. Tvalues are presented in parentheses. See Appendix A for variable definitions. The results of industry dummies and control variables are not reported. ${ }^{* * *},{ }^{* *}$, and $*$ indicate significance at the $0.1 \%, 1 \%$ and $5 \%$ levels. 